\title{
Effect of Cumulus Cells on the Efficiency of Vitrified-Thawed Immature Cattle Oocytes
}

\author{
Samia Mohamed Abd-El Rheem ${ }^{1 *}$, Suzan Elsharkawy ${ }^{2}$ \\ ${ }^{1}$ Theriogenology Department, Faculty of Veterinary Medicine, Alexandria University, Alexandria, Egypt \\ ${ }^{2}$ Gynecology and Obstetrics Department, Faculty of Medicine, Alexandria University, Alexandria, Egypt

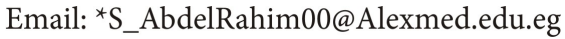

How to cite this paper: Abd-El Rheem, S.M. and Elsharkawy, S. (2019) Effect of Cumulus Cells on the Efficiency of Vitrified-Thawed Immature Cattle Oocytes. Open Journal of Obstetrics and Gynecology, 9, 669-678.

https://doi.org/10.4236/ojog.2019.95066

Received: April 23, 2019

Accepted: May 18, 2019

Published: May 21, 2019

Copyright $\odot 2019$ by author(s) and Scientific Research Publishing Inc. This work is licensed under the Creative Commons Attribution International License (CC BY 4.0).

http://creativecommons.org/licenses/by/4.0/

\begin{abstract}
The present work was designed to examine the effect of the presence or absence of cumulus cells on the efficiency of vitrification of immature cattle oocytes. In our experiment, we had two groups: group 1, immature cattle oocytes with cumulus cells and group 2, immature cattle oocytes without cumulus cells. The two groups underwent vitrification using $20 \%$ ethylene glycol and 20\% DMSO, and then thawed, and in vitro matured in TCM-199 medium and examined after 22 hours for assessment of nuclear maturation. Higher survival rate $(\mathrm{p}<0.05)$ after thawing was observed in group $1(84.6 \%)$ than group $2(57.8 \%)$. After in-vitro maturation, the rate of MII oocytes was significantly higher $(\mathrm{p}<0.05)$ in group $1(74.4 \%)$ than group $2(47.7 \%)$. In conclusion, the cumulus cells are very important in increasing the survivability and developmental rate of vitrified-thawed immature cattle oocytes.
\end{abstract}

\section{Keywords}

Cumulus Cells, Vitrified-Thawed Immature Oocytes, Cattle

\section{Introduction}

Oocytes vitrification provides several benefits for assisted reproductive technologies (ART). For human programs, it can decrease the number of embryos produced in each stimulation cycle, and allows synchronization in donor-recipient cycles and most importantly, it gives hope for young women receiving cancer treatment to preserve their fertility. In animals, vitrification techniques allow preservation of genetic varieties, and of course, it increases data useful for animal research and breeding programs [1] [2].

Unfortunately, oocytes are very vulnerable for vitrification methods because of their high fat concentrations and low surface-to-volume ratio. Moreover, they 
have such a delicate structure (the zona, cell membrane, cortical granules, metaphase plate and germinal vesicle) that can be seriously disrupted during freezing and warming procedures [3]. During oocyte vitrification, rupture of the cell membrane, destruction of the metaphase plate, premature extrusion of the cortical granules and zona hardening can accidently occur, leading to interruption of physiological fertilization of the vitrified-thawed oocyte [4].

Human assisted reproductive techniques centers have overcome these problems, and many laboratories have reported the development of a good blastocyst and live babies from vitrified-thawed oocytes at rates equals to those obtained from freshly fertilized oocytes [5]. However, the vitrified-warmed bovine oocyte fertilization rates and developments still lower when compared to their fresh matches, as bovine oocytes are more vulnerable for cooling with their higher lipid content [6].

To achieve success in oocyte vitrification, it depends on multiple factors that have been studied carefully for many years [7]. These factors may be divided into two main groups: oocyte-related factors and technical factors. Oocyte-related factors include the presence or absence of cumulus cells and the stage of development of the oocyte itself (mature or germinal vesicle), while technical factors refer to different stimulation protocols, cryoprotectants (CPAs), and machines used. In the last decade, most of these factors have been studied, but some have not, for example, the effect of cumulus cells during the process of vitrification is still unclear.

In cattle, it is well understood that the cumulus cells are essential for perfect maturation, fertilization, and of course embryo development [8] [9]. However, it is still unclear if cumulus cells are useful for bovine oocyte vitrification of [10] [11]. It has been proposed that cumulus cells may help to protect against cryo-injuries during vitrification by means of decreasing the release of cortical granules and stopping premature zona hardening [12]. Meanwhile, keeping cumulus cells during cryopreservation process may also limit the exchange of water and CPAs, causing inadequate dehydration, CPA entry and consecutive formation of ice crystals, which will lead to an inappropriate oocyte protection [13].

The meiotic stages for oocyte vitrification are ranging from germinal vesicle (GV) [14], Germinal vesicle break down (GVBD) [15] through meiosis II (MII), [16] which has been described as the most favorable stage for vitrification. Chilling injury is reported to be more common in immature oocytes, probably due to low membrane stability and high susceptibility of the cytoskeleton [17]. On the other hand, mature oocytes have shown increase in chromosomal aberrations, owing to alterations in the meiotic spindle [18].

\section{Materials \& Methods}

\subsection{Collection of Ovaries}

This study was done during the period from October 2018 till February 2019 at Elshat by hospital fertility center, Alexandria University; Twenty six ovaries were 
collected from slaughter house and placed into isothermal container containing warm normal saline solution at $37^{\circ} \mathrm{C}$, and transported to laboratory within $2 \mathrm{hrs}$. At the laboratory, ovaries were washed once with $70 \%$ ethanol and at least three times with normal saline solution supplemented with $100 \mathrm{IU} / \mathrm{ml}$ penicillin and $100 \mu \mathrm{g} / \mathrm{ml}$ streptomycin at $37^{\circ} \mathrm{C}$ [19]. The cumulus oocyte complex (COCs) was aspirated from follicles of $2-8 \mathrm{~mm}$ diameter and placed into Petri dish containing $5 \mathrm{ml}$ aspiration medium ( $5 \mathrm{ml}$ Phosphate buffer saline (PBS) and $3 \mathrm{mg} / \mathrm{ml}$ bovine serum albumin (BSA) and $50 \mu \mathrm{g} / \mathrm{ml}$ gentamycin sulphate), oocyte pickup was done using stereomicroscope at $90 \mathrm{x}$ magnification power (Olymbus company). Oocytes with an unexpanded cumulus mass, having two or more layers of cumulus cells and with a homogeneous, granular cytoplasm were used for vitrification.

229 Oocytes were divided in to two groups; group 1: 119 oocytes with cumulus cells, and group 2: 110 decomulated oocytes, done by repeated gentle pipetting using $100 \mu \mathrm{l}$ pipette under stereomicroscope.

\subsection{Vitrification of Immature Oocytes Groups}

The two groups of immature oocytes with cumulus cells and without cumulus cells were exposed to the vitrification solution in a two-step manner (which was used to improve the cleavage rate and the developmental competence of in-vitro maturation bovine oocytes subjected to vitrification) [20], by equilibrating oocytes serially in vitrification solution (VS1) (10\% Ethylene Glycol (EG) and 10\% Dimethyl sulfo-Oxide (DMSO) in holding medium) for $1 \mathrm{~min}$, before exposing them to the final concentration of the vitrification solution 2 (VS2) $(0.35 \mathrm{~m} \mathrm{su}$ crose, 20\% EG and 20\% DMSO in holding medium). Holding media consisted of tissue culture media TCM-199, 10\% Fetal Calf Serum (FCS) and $50 \mu \mathrm{g} / \mathrm{ml}$ gentamycin sulfate [21].

Oocytes were loaded into the $0.25 \mathrm{ml}$ French straw by using micro-classic pipette (Karl Hecht No. 558). Around 25 - 30 oocytes were loaded per straw. Loading of oocytes take one min from exposing them to VS2 till straws were put into liquid nitrogen and kept for at least 7 days. For thawing, straws were inserted into a $37^{\circ} \mathrm{C}$ water bath for $10-15$ seconds. Immediately the vitrified-warmed oocytes were transported to fresh thawing medium containing 0.5 $\mathrm{m}$ sucrose. A three-step process was used for dilution of sucrose gradually $(0.5$, 0.33 and $0.17 \mathrm{~m}$ sucrose each in holding medium, with $1 \mathrm{~min}$ equilibration in each solution) [21]. Oocytes were then washed many times with fresh maturation medium (consisted of TCM-199 supplemented with 10\% FCS, $10 \mu \mathrm{g} / \mathrm{ml}$ follicle stimulating hormone (FSH) (Foltrobin-V from Bioniche), $50 \mu \mathrm{g} / \mathrm{ml}$ gentamycin sulphate and $100 \mathrm{ng} / \mathrm{ml}$ Insulin like growth factor (IGF-1)).

\subsection{Morphological Evaluation of Vitrified-Thawed Immature Cattle Oocytes}

Oocytes were examined under an inverted microscope. The criteria used for as- 
sessing the post-thaw morphology of vitrified-thawed oocytes [21] were as follows:

1) Normal oocytes: with spherical, symmetrical shape and intact cumulus cells with homogenous cytoplasm;

2) Abnormal oocytes: with ruptured zonapellucida or ruptured vitelline membrane or fragmented cytoplasm with signs of degeneration.

\subsection{IVM of Vitrified-Thawed Oocytes}

Only the morphologically normal vitrified-thawed oocytes were cultured according to their groups in four well culture plates containing $500 \mu \mathrm{l}$ of maturation medium) at $5 \% \mathrm{CO}_{2}, 95 \%$ humidity at $38.5^{\circ} \mathrm{C}$ for $22 \mathrm{hrs}$.

\subsection{Assessing of Nuclear Maturation of IVM Oocytes}

At the end of maturation period, oocytes in group 1 were decomulated (the cumulus cells were removed by repeated gentle pipetting using $100 \mu$ pipette). The presence of first polar body in the perivetteline space (MII) was the criterion for nuclear maturation of the oocytes. Comparison of the two studied groups was done according to:

- Oocytes with first polar body (matured oocytes). M II

- Oocytes without first polar body MI, GV

- Degenerated oocytes.

\subsection{Statistical Analysis of the Data}

Data were fed to the computer and analyzed using IBM SPSS software package version 22. Quantitative data were described using mean and standard deviation error of mean. Comparison between the different studied groups was analyzed using independent T-test. Significance of the obtained results was judged at the $5 \%$ level.

\section{Results}

In this experiment we observed the percentage of recovered oocytes after thawing was significantly higher $(\mathrm{P}<0.05)$ in immature oocytes with cumulus cells group (93.2\%) than immature oocytes without CCs group (69.1\%). Loss of oocytes during the process of freezing and thawing occurred due to sticking of oocytes on the inner wall of straws, adherence to cracks or rough surfaces or oocyte disintegration due to improper vitrification.

Morphologically normal oocytes showed higher significant values $(\mathrm{P}<0.05)$ in immature oocytes with cumulus cells group (84.6\%) than immature oocytes without cumulus cells group (57.8\%) as shown in Table 1.

Also, we observed the abnormalities after thawing (of vitrified immature cattle oocyte first and second groups) were mainly:zona crack (23.5\% vs. $46.8 \%)$, change in shape ( $64.2 \%$ vs. $21.8 \%)$ and leakage ( $23.5 \%$ vs. $31.2 \%)$ respectively, as shown in Table 2. 
We recorded the percentage of oocytes with $1^{\text {st }} \mathrm{Pb}$ (polar body) which was significantly higher $(\mathrm{P}<0.05)$ in oocytes with cumulus cells group $(74.4 \%)$ than oocytes without cumulus cells group (47.7\%). We recorded the nuclear maturation of the two groups; oocytes showed MI was significantly higher in oocytes with cumulus cells than oocytes without cumulus cells (29.1\% vs. $17.3 \%$, respectively), GVBD showed no significant difference between the two groups $(20.8 \%$ vs. $21.7 \%$, respectively) and the GV state was significantly higher in oocytes without cumulus cells than oocytes with cumulus cells $(20.8 \%$ vs. $109 \%-30.4 \%$, respectively). We recorded degenerated oocytes after in-vitro maturation of vitrified-thawed immature cattle oocytes. The percentages of oocytes that undergo degeneration were non-significant $(\mathrm{P}<0.05)$ in oocytes with cumulus cells group and oocytes without cumulus cells $(29.1 \%, 30.4 \%$ respectively), as shown in Table 3.

Table 1. Effect of cumulus cells on morphology of immature oocytes after thawing.

\begin{tabular}{|c|c|c|c|c|c|c|}
\hline & \multicolumn{3}{|c|}{$\begin{array}{l}\text { Oocytes with } \\
\text { cumulus cells }\end{array}$} & \multicolumn{3}{|c|}{$\begin{array}{l}\text { Oocytes without } \\
\text { cumulus cells }\end{array}$} \\
\hline & No. & Mean \pm S.E. & $\%$ & No. & Mean \pm S.E. & $\%$ \\
\hline No. of oocytes & 119 & $19.8 \pm 3.4$ & & 110 & $18.3 \pm 6.5$ & \\
\hline Recovered oocytes & 111 & $18.5 \pm 3.7$ & $93.2^{\mathrm{a}}$ & 76 & $12.7 \pm 6.0$ & $69.1^{\mathrm{b}}$ \\
\hline $\begin{array}{l}\text { Morphologically } \\
\text { abnormal oocytes }\end{array}$ & 17 & $2.8 \pm 1$ & $15.3^{\mathrm{a}}$ & 32 & $5.3 \pm 2.3$ & $42.1^{\mathrm{b}}$ \\
\hline $\begin{array}{l}\text { Morphologically } \\
\text { normal and } \\
\text { cultured oocytes }\end{array}$ & 94 & $15.7 \pm 3.9$ & $84.6^{\mathrm{a}}$ & 44 & $7.3 \pm 4$ & $57.8^{\mathrm{b}}$ \\
\hline
\end{tabular}

a-b subscript in same raw are significantly different $(\mathrm{p}<0.05)$.

Table 2. Morphological abnormalities observed in the two groups of vitrified thawed immature oocytes.

\begin{tabular}{cccc}
\hline & Criteria & $\begin{array}{c}\text { With } \\
\text { cumulus cells }\end{array}$ & $\begin{array}{c}\text { Without } \\
\text { cumulus cells }\end{array}$ \\
\hline Zona crack & No. & 4 & 15 \\
Mean \pm S.E. & $0.7 \pm 0.8$ & $2.5 \pm 1.1$ \\
shape & $\%$ & $23.5^{\mathrm{a}}$ & $46.8^{\mathrm{b}}$ \\
& No. & 9 & 7 \\
leakages & $\%$ & $1.5 \pm 1.1$ & $1.2 \pm 0.8$ \\
& Mean \pm S.E. & $64.2^{\mathrm{a}}$ & $21.8^{\mathrm{a}}$ \\
& $\%$ & 4 & 10 \\
\hline
\end{tabular}

a-b subscript in same column are significantly different $(\mathrm{p}<0.05)$. 
Table 3. Effect of cumulus cells on the nuclear maturation of vitrified-thawed immature oocytes.

\begin{tabular}{cccccccc}
\hline & \multicolumn{3}{c}{$\begin{array}{c}\text { Oocytes with } \\
\text { cumulus cells }\end{array}$} & \multicolumn{3}{c}{$\begin{array}{c}\text { Oocytes without } \\
\text { cumulus cells }\end{array}$} \\
\cline { 2 - 7 } & No. & Mean \pm S.E. & $\%$ & No. & Mean \pm S.E. & $\%$ \\
\hline $\begin{array}{c}\text { Oocytes with } \\
\text { 1st Pb (MII) }\end{array}$ & 70 & $11.7 \pm 3.6$ & $74.4 \mathrm{a}$ & 21 & $3.5 \pm 2.2 \mathrm{~b}$ & $47.7 \mathrm{~b}$ \\
M-I & 7 & $1.2 \pm 1.0$ & $29.1 \mathrm{a}$ & 4 & $0.7 \pm 0.8$ & $17.3 \mathrm{~b}$ \\
GVBD & 5 & $0.8 \pm 0.8$ & $20.8 \mathrm{a}$ & 5 & $0.8 \pm 1.3$ & $21.7 \mathrm{a}$ \\
G.V & 5 & $0.8 \pm 1$ & $20.8 \mathrm{a}$ & 7 & $1.2 \pm 1.2$ & $30.4 \mathrm{~b}$ \\
Degenerated & 7 & $1.2 \pm 0.4$ & $29.1 \mathrm{a}$ & 7 & $1.2 \pm 0.8$ & $30.4 \mathrm{a}$ \\
\hline
\end{tabular}

a-b subscript in same raw are significantly different $(\mathrm{p}<0.05)$.

\section{Discussion}

The influence of cumulus cells presence during vitrification process has been studied for several years, but different results have been found in many species. In our experiment we used immature cattle oocytes which were selected for freezing on the basis of their morphological appearance and didn't distinguish between those cells which were physiologically destined to atresia and those which were destined to be dominant oocytes. We observed that removal of cumulus cells before vitrification decrease the survival rate and meiotic competence of immature cattle oocytes. Our results were in agreement with Tharasanit et al., [22] who reported that The cumulus cells removal prior to in-vitro maturation or vitrification have shown to have a detrimental effect on oocyte morphology for both immature and mature vitrified equine oocytes resulted in reduced meiotic competence, MII spindle and chromatin quality also the mouse oocytes [23] [24], bovine [25], buffalo oocytes [26] and goat oocytes [27]. In humans, a useful effect of cumulus cells presence for the survival of mature oocytes was documented [28] [29]. It is generally accepted that cumulus-oocyte communication via an intact corona radiata is necessary for oocytes during IVM and 6- improve fertilization rates during IVF [9]. Cumulus cells removal before vitrification increases the meiotic promoting factor activity and accelerates the transition to metaphase stage and the redistribution of cortical 8- granules [11].

In contrast, Bogliolo, et al. [30] reported that immature ovine oocytes vitrified without cumulus cells showed a significantly higher survival rate than those with cumulus cells. Gasparrini et al. [31] reported that cumulus cells play a detrimental role during the vitrification of buffalo oocytes. Horvath and Seidel [32] partially removed cumulus cells to cryopreserve bovine oocytes and have better results than oocytes with cumulus cells or denuded oocytes. Chian et al. [10] reported that cumulus cells have a harmful effect on the survivability rate of vitrified mature oocytes also Ortiz-Escribano [33] reported that cumulus cells reduce survival after the vitrification of mature bovine oocytes.

However, in human Minasi et al. [34] reported that "no differences in the sur- 
vival of oocytes with cumulus cells compared with denuded oocytes, also no differences were found in the survival rate between cumulus complex oocytes and denuded ovine oocytes" [35]. Dinnyes et al. [36] observed no effect when cumulus cells were present during vitrification of bovine oocytes. Similarly, Zhou et al. [11] did not observe any difference in the survival of mature bovine oocytes when they were vitrified with or without cumulus cells.

\section{Conclusion}

In conclusion, our data indicate that cumulus cells are necessary to improve the efficiency of vitrification of immature cattle oocytes and the meiotic competence after thawing. The removal of cumulus cells before vitrification leads to decrease in the survival rate, increases the abnormalities and also reduces the meiotic competence.

\section{Conflicts of Interest}

The authors declare no conflicts of interest regarding the publication of this paper.

\section{References}

[1] Ledda, S., Leoni, G., Bogliolo, L. and Naitana, S. (2001) Oocyte Cryopreservation and Ovarian Tissue Banking. Theriogenology, 55, 1359-1371. https://doi.org/10.1016/S0093-691X(01)00487-3

[2] Pereira, R.M. and Marques, C.C. (2008) Animal Oocyte and Embryo Cryopreservation. Cell Tissue Bank, 9, 267-277. https://doi.org/10.1007/s10561-008-9075-2

[3] Chen, S.U., Lien, Y.R., Chao, K.H., Ho, H.N., Yang, Y.S. and Lee, T.Y. (2003) Effects of Cryopreservation on Meiotic Spindles of Oocytes and Its Dynamics after Thawing: Clinical Implications in Oocyte Freezing a Review Article. Molecular and Cellular Endocrinology, 202, 101-107. https://doi.org/10.1016/S0303-7207(03)00070-4

[4] Mavrides, A. and Morroll, D. (2005) Bypassing the Effect of Zona Pellucida Changes on Embryo Formation Following Cryopreservation of Bovine Oocytes. European Journal of Obstetrics \& Gynecology and Reproductive Biology, 118, 66-70. https://doi.org/10.1016/j.ejogrb.2004.06.025

[5] Cobo, A., Kuwayama, M., Pérez, S., Ruiz, A., Pellicer, A. and Remohí, J. (2008) Comparison of Concomitant Outcome Achieved with Fresh and Cryopreserved Donor Oocytes Vitrified by the Cryotop Method. Fertility and Sterility, 89, 1657-1664. https://doi.org/10.1016/j.fertnstert.2007.05.050

[6] Martino, A., Pollard, J.W. and Leibo, S.P. (1996) Effect of Chilling Bovine Oocytes on Their Developmental Competence. Molecular Reproduction and Development, 45, 503-512. https://doi.org/10.1002/(SICI)1098-2795(199612)45:4<503::AID-MRD13>3.0.CO;2$\underline{\mathrm{X}}$

[7] Saragusty, J. and Arav, A. (2011) Current Progress in Oocyte and Embryo Cryopreservation by Slow Freezing and Vitrification. Reproduction, 141, 1-19. https://doi.org/10.1530/REP-10-0236

[8] Zhang, L., Jiang, S., Wozniak, P.J., Yang, X. and Godke, R.A. (1995) Cumulus Cell Function during Bovine Oocyte Maturation, Fertilization, and Embryo Develop- 
ment in Vitro. Molecular Reproduction and Development, 40, 338-344. https://doi.org/10.1002/mrd.1080400310

[9] Tanghe, S., Van Soom, A., Mehrzad, J., Maes, D., Duchateau, L. and de Kruif, A. (2003) Cumulus Contributions during Bovine Fertilization in Vitro. Theriogenology, 60, 135-149. https://doi.org/10.1016/S0093-691X(02)01360-2

[10] Chian, R.C., Kuwayama, M., Tan, L., Tan, J., Kato, O. and Nagai, T. (2004) High Survival Rate of Bovine Oocytes Matured in Vitro Following Vitrification. Journal of Reproduction and Development, 50, 685-696. https://doi.org/10.1262/jrd.50.685

[11] Zhou, X.L., Al Naib, A., Sun, D.W. and Lonergan, P. (2010) Bovine Oocyte Vitrification Using the Cryotop Method: Effect of Cumulus Cells and Vitrification Protocol on Survival and Subsequent Development. Cryobiology, 61, 66-72. https://doi.org/10.1016/j.cryobiol.2010.05.002

[12] Vincent, C., Pickering, S.J. and Johnson, M.H. (1990) The Hardening Effect of Dimethylsulphoxide on the Mouse Zona Pellucida Requires the Presence of an Oocyte and Is Associated with a Reduction in the Number of Cortical Granules Present. Journal of Reproduction and Fertility, 89, 253-259. https://doi.org/10.1530/jrf.0.0890253

[13] Gook, D.A., Osborn, S.M. and Johnston, W.I. (1993) Cryopreservation of Mouse and Human Oocytes Using 1,2-Propanediol and the Configuration of the Meiotic Spindle. Human Reproduction, 8, 1101-1109. https://doi.org/10.1093/oxfordjournals.humrep.a138201

[14] Magnusson, V., Feitosa, W.B., Goissis, M.D., Yamada, C., Tavares, L.M., Ortiz, M.E., Assumpcao, D. and Visintin, J.A. (2008) Bovine Oocyte Vitrification: Effect of Ethylene Glycol Concentration and Meiotic Stages. Animal Reproduction Science, 106, 265-273. https://doi.org/10.1016/j.anireprosci.2007.05.001

[15] Barnes, F.L., Damiani, P., Looney, C.R. and Duby, R.T. (1997) The Meiotic Stage affects Subsequent Development of Cooled Bovine Oocytes. Theriogenolog, 47, 183. https://doi.org/10.1016/S0093-691X(97)82310-2

[16] Men, H., Monson, R.L. and Rutledge, J.J. (2002) Effect of Meiotic Stages and Maturation Protocols on Bovine Oocyte's Resistance to Cryopreservation. Theriogenology, 57, 1095-1103. https://doi.org/10.1016/S0093-691X(01)00679-3

[17] Hong, S.W., Chung, H.M., Lim, J.M., Ko, J.J., Yoon, T.K., Yee, B. and Cha, K.Y. (1999) Improved Human Oocytes Development after Vitrification: A Comparison of Thawing Methods. Fertility and Sterility, 72, 142-146. https://doi.org/10.1016/S0015-0282(99)00199-5

[18] Luciano, A.M., Chigioni, S., Lodde, V., Franciosi, F., Luvoni, G.C. and Modina, S.C. (2009) Effect of Different Cryopreservation Protocols on Cytoskeleton and Gap Junction Mediated Communication Integrity in Feline Germinal Vesicle Stage Oocytes. Cryobiology, 59, 90-95. https://doi.org/10.1016/j.cryobiol.2009.05.002

[19] Leibfried-Rutledge, M.L., Critser, E.S., Eyestone, W.H., Northey, D.L. and First, N.L. (1987) Development Potential of Bovine Oocytes Matured in Vitro or in Vivo. Biology of Reproduction, 36, 376-383. https://doi.org/10.1095/biolreprod36.2.376

[20] Otoi, T., Yamamoto, K., Koyama, N., Tachikawa, S. and Suzuki, T. (1998) Cryopreservation of Mature Bovine Oocytes by Vitrification in Straws. Cryobiology, 37, 77-85. https://doi.org/10.1006/cryo.1998.2103

[21] Gautam, S.K., Verma, V., Palta, P., Chauhan, M.S. and Manik, R.S. (2008) Effect of Type of Cryoprotectant on Morphology and Developmental Competence of in $\mathrm{Vi}$ tro-Matured Buffalo (Bubalusbubalis) Oocytes Subjected to Slow Freezing or Vitrification. Reproduction and Fertility Development, 20, 490-496. 
https://doi.org/10.1071/RD07203

[22] Tharasanit, T., Colleoni, S., Galli, C., Colenbrander, B. and Stout, T.A.E. (2009) Protective Effects of the Cumulus-Corona Radiata Complex during Vitrification of Horse Oocytes. Reproduction, 137, 391-401. https://doi.org/10.1530/REP-08-0333

[23] Miyake, T., Kasai, M., Zhu, S.F., Sakurai, T. and Machida, T. (1993) Vitrification of Mouse Oocytes and Embryos at Various Stages of Development in an Ethylene Glycol Based Solution by a Simple Method. Theriogenology, 40, 121-134. https://doi.org/10.1016/0093-691X(93)90346-7

[24] Suo, L., Zhou, G.B., Meng, Q.G., Yan, C.L., Fan, Z.Q. and Zhao, X.M. (2009) OPS Vitrification of Mouse Immature Oocytes before or after Meiosis: The Effect on Cumulus Cells Maintenance and Subsequent Development. Zygote, 17, 71-77. https://doi.org/10.1017/S0967199408005091

[25] Modina, S., Beretta, M., Lodde, V., Lauria, A. and Luciano, A.M. (2004) Cytoplasmic Changes and Developmental Competence of Bovine Oocytes Cryopreserved without Cumulus Cells. European Journal of Histochemistry, 48, 337-346.

[26] Attanasio, L., De Rosa, A., De Blasi, M., Neglia, G., Zicarelli, L., Campanile, G. and Gasparrini, B. (2010) The Influence of Cumulus Cells during in Vitro Fertilization of Buffalo (Bubalusbubalis) Denuded Oocytes That Have Undergone Vitrification. Theriogenology, 74, 1504-1508. https://doi.org/10.1016/j.theriogenology.2010.05.014

[27] Purohit, G.N., Meena, H. and Solanki, K. (2012) Effects of Vitrification on Immature and in Vitro Matured, Denuded and Cumulus Compact Goat Oocytes and Their Subsequent Fertilization. Journal of Reproduction and Infertility, 13, 53-59. https://doi.org/10.6000/1927-520X.2012.01.01.14

[28] Imoedemhe, D.G. and Sigue, A.B. (1992) Survival of Human Oocytes Cryopreserved with or without the Cumulus in 1,2-Propanediol. Journal of Assisted Reproduction and Genetics, 9, 323-327. https://doi.org/10.1007/BF01203954

[29] Kuwayama, M., Vajta, G., Kato, O. and Leibo, S.P. (2005) Highly Efficient Vitrification Method for Cryopreservation of Human Oocytes. Reproductive BioMedicine Online, 11, 300-308. https://doi.org/10.1016/S1472-6483(10)60837-1

[30] Bogliolo, L., Ariu, F., Fois, S., Rosati, I., Zedda, M.T., Leoni, G. and Ledda, S. (2007) Morphological and Biochemical Analysis of Immature Ovine Oocytes Vitrified with or without Cumulus Cells. Theriogenology, 68, 1138-1149.

https://doi.org/10.1016/j.theriogenology.2007.08.013

[31] Gasparrini, B., Attanasio, L., De Rosa, A., Monaco, E., Di Palo, R. and Campanile, G. (2007) Cryopreservation of in Vitro Matured Buffalo (Bubalusbubalis) Oocytes by Minimum Volumes Vitrification Methods. Animal Reproduction Science, 98, 335-342. https://doi.org/10.1016/j.anireprosci.2006.04.046

[32] Horvath, G. and Seidel Jr., G.E. (2006) Vitrification of Bovine Oocytes after Treatment with Cholesterol-Loaded Methyl-b-Cyclodextrin. Theriogenology, 66, 1026-1033. https://doi.org/10.1016/j.theriogenology.2006.03.004

[33] Ortiz-Escribano, N., Smits, K., Piepers, S., Van den Abbeel, E., Woelders, H. and Van Soom, A. (2016) Role of Cumulus Cells during Vitrification and Fertilization of Mature Bovine Oocytes: Effects on Survival, Fertilization, and Blastocyst Development. Theriogenology, 86, 635-641.

https://doi.org/10.1016/j.theriogenology.2016.02.015

[34] Minasi, M.G., Fabozzi, G., Casciani, V., Ferrero, S., Litwicka, K. and Greco, E. (2012) Efficiency of Slush Nitrogen Vitrification of Human Oocytes Vitrified with or without Cumulus Cells in Relation to Survival Rate and Meiotic Spindle Compe- 
tence. Fertility and Sterility, 97, 1220-1225.

https://doi.org/10.1016/j.fertnstert.2012.02.022

[35] Zhang, J., Nedambale, T.L., Yang, M. and Li, J. (2009) Improved Development of Ovine Matured Oocyte Following Solid Surface Vitrification (SSV) Effect of Cumulus Cells and Cytoskeleton Stabilizer. Animal Reproduction Science, 110, 46-55. https://doi.org/10.1016/j.anireprosci.2007.12.023

[36] Dinnyes, A., Dai, Y.P., Jiang, S. and Yang, X.Z. (2000) High Developmental Rates of Vitrified Bovine Oocytes Following Parthenogenetic Activation, in Vitro Fertilization, and Somatic Cell Nuclear Transfer. Biology of Reproduction, 63, 513-518.

https://doi.org/10.1095/biolreprod63.2.513 